Uniwersytet Gdański

\title{
My naród - czyli kto? Kategoria my - oni w przemówieniach Jarosława Kaczyńskiego z okazji rocznic smoleńskich
}

\begin{abstract}
Streszczenie
Przedmiotem artykułu jest pokazanie roli, jaką pełni w przemówieniach Jarosława Kaczyńskiego (czyli tekstach politycznych o charakterze perswazyjnym) kategoria osoby w uykreowaniu obrazu narodu polskiego po katastrofie smoleńskiej. Kaczyński stosuje formę my dla określenia uspólnoty, którą tworzy ta część narodu, która myśli tak samo jak on. Forma oni ma w wystąpieniach Kaczyńskiego trzy zastosowania: określa tych, którzy zginęli w katastrofie, nazywa ludzi, którzy są zuolennikami J. Kaczyńskiego, prowadzą śledztwo dotyczące katastrofy, zbierają pieniądze na pomniki itp. Trzecią grupę oni prezentują przeciunicy polityczni. Kaczyński stosuje wreszcie formy bezosobowe. Określają one uroga politycznego, pokazują jego szczególnie niegodziwe działania. Tym największym wrogiem jest polski rząd z premierem Donaldem Tuskiem.
\end{abstract}

Słowa kluczowe: język polityki, propaganda, relacje nadawczo-odbiorcze, aksjologia, językowa kreacja narodu.

\section{We the People - who is it? Category we - they in the speeches of Jaroslaw Kaczynski on the occasion of Smoleńsk anniversary}

\begin{abstract}
The matter of this article is to show the role of the category of a person in the creation of the image of the Polish society after the Smoleńsk catastrophe in J. Kaczyński's speeches. Kaczyński uses the form 'us' to specify the community of people that think in the way he thinks. The form 'they' has in his speeches three tasks: it specifies people who died in the catastrophe, it specifies the group of people who support Kaczyński and collect money for sculptures etc. The third group is presented by his political enemies. Kaczyński uses also impersonal forms. The specify the political enemies and show their bad actions. The biggest enemy is the Polish government with Donald Tusk.
\end{abstract}

Key words: language of politics, propaganda, transnational relations, axiology, linguistic creation of the nation.

Dnia 10 kwietnia 2010 roku pod Smoleńskiem doszło do tragicznego uypadku polskiego samolotu rządowego wiozącego polską delegację na obchody 70. rocznicy zbrodni katyńskiej. Zginęło w nim 96 osób, wśród nich zaś: prezydent Rzeczypospolitej Polskiej 
Lech Kaczyński z małżonką, ostatni prezydent RP na uchodźstwie Ryszard Kaczorouski, wicemarszałkowie Sejmu i Senatu, grupa parlamentarzystów, dowódcy wszystkich rodzajów Sił Zbrojnych RP, przedstawiciele instytucji państwowych, ministerstw, organizacji kombatanckich i społecznych oraz duchouni, a także załoga samolotu.

Ta niewyobrażalna tragedia stała się impulsem, który na chwilę zjednoczył polski naród, podzielony sporami politycznymi. Niestety, już po kilku dniach spory rozgorzały na nowo, a tematem, który poróżnił polskie społeczeństwo, jak nigdy przedtem, stało się pytanie o przyczynę katastrofy.

Ta kwestia powraca co miesiąc w czasie obchodzonych przez przedstawicieli i zwolenników Prawa i Sprawiedliwości, tak zwanych miesięcznic smoleńskich. Punktem kulminacyjnym tych wydarzeń jest każdorazowo przemówienie Jarosława Kaczyńskiego, prezesa PIS i brata prezydenta Lecha Kaczyńskiego, który zginął w katastrofie.

Przedmiotem artykułu jest pokazanie roli, jaką pełni w przemówieniach J. Kaczyńskiego kategoria osoby w wykreowaniu obrazu narodu polskiego po katastrofie smoleńskiej.

Przemówienia te należą do gatunku języka zwanego językiem polityki. Bogdan Walczak definiuje go jako

funkcjonalną odmianę języka ogólnego [...], stosowaną w tekstach, które: (1) są wytwarzane przez środowisko polityków i ludzi z nimi związanych [...] oraz dziennikarzy specjalizujących się w problematyce politycznej, (2) są adresowane intencjonalnie do wszystkich użytkowników języka ogólnego, (3) dotyczą sfery polityki, (4) odznaczają się dominacją funkcji perswazyjnej $[. . .]^{1}$.

Analizując kategorię osoby w przemówieniach Kaczyńskiego, należy podkreślić, że pełni ona w dyskursie przede uszystkim właśnie funkcję perswazyjną. Piotr Lewiński definiuje tę funkcję jako

usiłowanie uzyskania realnego upłyuu na sposób myślenia lub postępowania odbiorcy, jednakże nie drogą bezpośredniego rozkazu, lecz metodą pośrednią, poprzez podporządkouanie założonemu celowi wszystkich pozostałych zachowań komunikacyjnych, które odbiorca byłby w stanie zrozumieć i właściwie zinterpretować ${ }^{2}$.

Do najważniejszych przejawów perswazji w sferze komunikacji zaliczyć należy: (1) emocjonalizację odbioru, czyli przypisanie składnikom wypowiedzi negatywnych (odnośnie do przeciunika) lub pozytywnych (autoprezentacja) emocji, odwołanie do

${ }^{1}$ B. Walczak, Co to jest język polityki [w:] Język a kultura. Język polityki a wspótczesna kultura polityczna, J. Anusiewicz, B. Siciński (red.), Wiedza o Kulturze, Wrocław 1994.

2 Zob.: J. Fras, Komunikacja polityczna: wybrane zagadnienia gatunków i języka wypowiedzi, Wydawnictwo Uniwersytetu Wrocłauskiego, Wrocław 2005, s. 84. Lewiński w swojej pracy posługuje się niewątpliwie definicją perswazji Stanisława Barańczaka, zob. idem, Stowo perswazja - kultura masowa, „Twórczość” nr 7, 1975. Por. też: I. Kamińska-Szmaj, Propaganda, perswazja, manipulacja - próba uporzadkowania pojęć [w:] Manipulacja w języku, red. P. Krzyżanouski, P. Nowak, Wydawnictwo Uniwersytetu Marii Curie-Skłodouskiej, Lublin 2004, s. 13-28; Z. Zaleska, Perswazja w języku polityki, „Dialogi Polityczne” 2008, nr 9, s. 256-258. 
resentymentów; (2) ustanowienie uspólnoty śuiata i wypowiedzi pomiędzy nadawcą a odbiorcą, co skraca dystans, ułatwia zrozumienie i przyjęcie komunikowanych treści; (3) stosowanie uproszczonego, kategorycznego wartościowania, na zasadzie nieskomplikowanej opozycji (np. my-oni, dobry-zły); (4) arbitralność definicji i ocen oraz takie przedstawianie problemu, że odbiorca ma poczucie bezalternatyuności uyboru3.

Relacje osobowe występujące $w$ dyskursie politycznym tak są zarysowane, że odbijają się w nich uszystkie wymienione przejawy persuazji.

W wystąpieniach Jarosława Kaczyńskiego podczas tak zuanych miesięcznic smoleńskich, obraz (i ocena) narodu nie są jednorodne. Naród, o którym mówi prezes PiS, został podzielony z perspektyuy języka na kilka niejednorodnych kategorii osobowych.

\section{My}

Pieruszą z nich stanowi 1 os. l. mn. - my, której celem nadrzędnym jest ustanowienie uspólnoty nadawczo-odbiorczej. Dzięki kategorii my, podmiot mówiący tworzy suój wizerunek poprzez kreację uspólnoty aksjologicznej, do której nadawca chce ułączyć odbiorcę. Jak podkreśla Katarzyna Kłosińska, nadawca przedstawia więc swój system wartości w taki sposób, by odbiorcy uznali go za własny"

Kaczyński w swoich wystąpieniach zuraca się pozornie do całego narodu, do wszystkich obywateli:

(1) Mamy prawo do prawdy jako obywatele i jako naród (2013),

by jednak natychmiast dodać:

(2) Mamy prawo i obowiązek o tę prawdę walczyć i będziemy walczyć, mamy obowiązek, dlatego że rację mają ci, którzy mówią, że jeśli się zgodzimy na to wszystko, co dzieje się wokót Smoleńska, to znaczy, że z Polska można wszystko zrobić (2013).

Zatem nasz naród (my), czyli ci, którzy mówia/myślą tak samo jak my. Jest jednak nieokreślona grupa myśląca i mówiąca inaczej. Tej grupy nadawca tu nie dookreśla, jednak sugeruje, że nie należy ona do narodu.

Zastosowanie formy my służy móucy do ukazania uspólnego celu zgromadzenia:

(3) Spotykamy się tu dzisiaj, a takich spotkań jest wiele w Polsce i poza Polska od 5 lat, bo zaczęty się w pierwszych chwilach po tragedii. Spotykamy się, by oddać hotd, żeby umocnić pamięć, pochylić głowę (2015).

\footnotetext{
${ }^{3}$ Zob. J. Fras, op. cit., s. 85.

${ }^{4}$ Zob. K. Kłosińska, Rola procesów nominacyjnych w tworzeniu opozycji „my”|"oni” w języku polityki po 1989 roku [w:] Manipulacja w języku, op. cit., s. 116.

${ }^{5}$ W nawiasie podaję rok, w którym wystąpienie zostało wygłoszone. Dokładny adres bibliograficzny poszczególnych fragmentów został zamieszczony w netografii.
} 
(4) Gromadzimy się dzisiaj z bólem, wspominamy tych, którzy zginęli. Ale jest w nas także nadzieja na to, że 6 lat trwające wysitki tych, którzy nie chca zapomnieć, przyniosa $w$ końcu rezultaty (2016).

My buduje poczucie jedności, łączy w przeżywaniu bólu, wspominaniu tych, którzy zginęli, oddawaniu hołdu, umacnianiu pamięci, pochyleniu głowy oraz daje nadzieję, że uspólne wysiłki [...] przyniosa oczekiwane od lat rezultaty.

Śuiadomość uspólnoty kreowanej przez mówcę ma wymiar historyczno-kulturowy:

(5) Łączy nas żałoba, żal $i$ wspomnienia, ale tączy nas też wiara $w$ znaczenie prawdy jako fundamentu naszej cywilizacji, który przeciwstawiamy ktamstwu. To w chrześcijaństwie ważne są słowa: prawda was wyzwoli. Bez tej wiary w naukę Chrystusa Zmartwychwstałego nie ma polskości (2014).

Zastosowanie formy zdania przeciustawnego: Łaczy nas żałoba, żal i wspomnienia, ale łaczy nas też wiara w znaczenie prawdy jako fundamentu naszej cywilizacji... ukazuje sposób wartościowania tej uspólnoty - opartej na prawdzie, odnoszącej się do korzeni cywilizacji, przeciustawionej kłamsturu. Można zatem wysunąć hipotezę, że ci, którzy do tej uspólnoty nie należą, są grupą opartą na kłamstuie. Nawiązanie do słów Jezusa: prawda was wyzwoli (J 8, 32) i odniesienie się do wiary chrześcijańskiej jako źródła polskości sprawiają, że mówca dzieli naród - na Polaków, czyli tych, którzy wierzą w Chrystusa Zmartuychustałego i nie-Polaków, którzy nie wierzą. Co więcej, można także odczytać supozycję: tylko nasza (ściśle określona, wyznająca te same poglądy) wspólnota może określić się mianem ludzi wierzących i mianem Polaków.

Kolejnym wyrażeniem, które tworzy uspólnotę my jest określenie polski patriota:

(6) Pamiętajcie, rechot przemysłu pogardy towarzyszył niejednemu polskiemu patriocie, ale ci, którzy byli w ten sposób atakowani, nie załamali się i my się też nie załamiemy. Dożyjemy, i to w niedtugim czasie, Polski, w której będa stawały pomniki Lecha Kaczyńskiego, ofiar katastrofy smoleńskiej (2013).

W tym wypadku polski patriota jest rozumiany szerzej. Tę grupę stanowili również ci, którzy zginęli w katastrofie, a którym wcześniej towarzyszył rechot pogardy. Zastosowanie tego kolokwializmu dewaluuje jeszcze bardziej przeciuników politycznych, tych, którzy u zgromadzeniu nie uczestniczą (ze względu na odmienne poglądy).

Forma 1 os. l. mn pozwala także określić uspólne cele:

(7) Musimy odbudować polska wspólnotę, mimo że są między nami różnice. Ale musi być jakaś wartość, która nie jest kwestionowana. Ta wartościa jest prawda. Bez prawdy nie ma demokracji, wolności, praworządności, praw obywatelskich, nie ma obywateli. Sa tylko manipulowani poddani (2015).

(8) Musimy iść droga, którą wskazywat prezydent Lech Kaczyński, ale żeby tą droga iść, musimy zwyciężyć. Żeby zwyciężyć, musimy walczyć o prawdę i wtedy nadejdzie ten dzień i prawda wyzwoli wolnych Polaków (2014). 
(9) Chociaż wtedy się nie udato, musi się udać. Musimy zmienić Polskę (2011).

(10) Bez prawdy o Smoleńsku nigdy nie zbudujemy silnego państwa, które będzie strzegło naszego bezpieczeństwa i porzadku publicznego opartego na solidarności $i$ sprawiedliwości. To państwo to jest to, czego Polska i Polacy najbardziej potrzebują (2015).

Celem nadrzędnym jest zmiana Polski, a drogą do celu jest prawda o Smoleńsku. Poutarzająca się w wielu przemówieniach silnie perswazyjna forma musimy pokazuje nie tylko uspólny cel, lecz także uspólne wartości: demokrację, wolność, praworządność, prawa obywatelskie, bezpieczeństwo oraz uspólnego bohatera - przywódcę: Musimy iść droga, którą wskazywał prezydent Lech Kaczyński.

Celem uspólnoty my jest zaróuno dojście do prawdy i zmiana Polski, jak i zachowanie jej dla potomnych - to kolejne zadanie, które czeka tę wspólnotę:

(11) Prawda musi się znaleźć $w$ polskich dokumentach, musi się znaleźć $w$ pracach historyków, w powszechnie dostępnych publikacjach, $w$ telewizji, $w$ radiu, $w$ filmach, w podręcznikach szkolnych i akademickich. Dopiero wtedy będziemy mogli powiedzieć, że wyciagnęliśmy wnioski z katastrofy smoleńskiej i jesteśmy silniejsi, jesteśmy gospodarzami we własnym polskim i bezpiecznym domu. Zwyciężymy i Polska będzie Polska (2015).

(12) Prawda musi się znaleźć $w$ książkach, podręcznikach, musimy to opisać, musimy znać fakty, to dzieło dopiero się dzisiaj zaczyna, bo do tej pory to byt pozór, byto udawanie (2016).

Liczne użycia czasounika musieć (zułaszcza u 1 os. l. mn.) stanowią nakaz dla odbiorców i ukazują cel, jakim jest konieczność napisania prawdy historycznej o katastrofie smoleńskiej. Należy zurócić uwagę na to, że słowa te zostały wypowiedziane pięć i sześć lat po uydarzeniu. Zatem można mówić o kolejnej supozycji: uszystko, co dotychczas powiedziano i napisano o tym tragicznym dla całego narodu wydarzeniu, nie jest prawdą. Tylko uspólnota my może prawdę odnaleźć i rozpouszechnić. Odnalezienie i opisanie prawdy stanie się przyczyną zuycięstwa. Hasło Polska będzie Polska (parafraza piosenki Jana Pietrzaka) oraz ucześniejsze stuierdzenie: dopiero wtedy będziemy mogli powiedzieć, że [...] jesteśmy gospodarzami we własnym polskim i bezpiecznym domu stanowią kolejną supozycję: obecna Polska nie jest prawdziwą i bezpieczną Polską, a my - obywatele nie jesteśmy gospodarzami w naszym kraju. Zatem władzę nad nami sprauują obcy.

Jarosław Kaczyński przestrzega nieustannie przed wrogiem, który robi uszystko, by prawda nigdy nie wyszła na jaw. Stąd konieczność kontynuowania misji nawet teraz, gdy władzę w Polsce sprauuje niepodzielnie rząd PiS:

(13) [...] nasza misja [...] trwa, ona ciagle ma sens, także dlatego, że ci którzy sa przeciw nam, maja już dzisiaj tylko jedna broń, poza kłamstwem oczywiście, ta bronia jest prowokacja. Musimy wiedzieć, że ona będzie stosowana i musimy umieć ja odrzucić, właściwie potraktować, bo to jest nasza droga do petnego zwycięstwa i przyjdzie to petne zwycięstwo - jestem o tym gtęboko przekonany (2017). 
Nadauca przestrzega przed podstępnym urogiem, posługującym się jakże groźną bronią: kłamstuem i prowokacją. Taka sytuacja wymaga wspólnych działań, stąd znowu pojawia się ciąg perswazyjnych uskazań: musimy wiedzieć, musimy umieć. Wspólna walka z wrogiem zapewni jednak ostateczne zuycięstwo. Ostatnie zdanie zawiera w sobie tak zwany operator zwiększający efektywność funkcji pragmatycznych (jestem o tym gtęboko przekonany). Jego zadaniem jest spowodowanie urażenia peuności, przekonanie odbiorcy o wiarygodności podanej treści, mimo że nie można jej

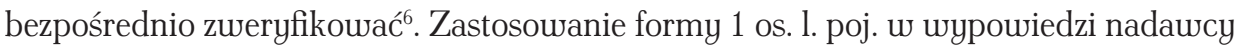
ukazuje go jako niekwestionowany autorytet i przywódcę wspólnotowego my.

\section{Oni}

Forma 3 os. l. mn. w komunikacji językowej pokazuje pewne wykluczenie, odcięcie się od uspólnoty my. Między ja/my i oni występuje najbardziej rozluźniona więź komunikacyjna, wynikająca z braku bezpośredniego kontaktu . Jednocześnie kategoria oni pomaga wzmocnić więź ze światem my przez ukazanie zagrożenia dla śuiata my systemem innych wartości - antywartości reprezentowanych przez oni ${ }^{8}$.

W przemówieniach Jarosława Kaczyńskiego kategoria ta nie jest jednak taka oczyuista. Forma oni określa bowiem trzy skrajnie różne grupy.

Pierusza, pozytyuna, to ci, którzy zginęli u katastrofie smoleńskiej:

(14) Trzeba ich pamięć uczcić dlatego, że mieli rację i potrafili prowadzić politykę w oparciu o tę rację. Trzeba ich uczcić godnie - we właściwym miejscu, we właściwy sposób (2015).

(15) I choć mówię to z bólem, musimy też pamiętać hańbę. Hańbę przemystu pogardy, knowań, porzucenia tych Polaków, którzy polegli, hańbę, która prowadziła do tego, że znieważane byty nawet ich ciała (2014).

(16) Zostali zdradzeni o świcie. To wiemy już dzisiaj na pewno, niezależnie od tego, jakie będa ostateczne ustalenia (2012).

(17) Zostali zdradzeni i to było haniebne, tak jak haniebne było oddanie śledztwa, przyjmowanie rosyjskich kłamstw, haniebne było obrażanie poległych i upokarzanie ich rodzin (2012).

Zastosowanie u pieruszym przykładzie zdania przyczynowego, pełniącego tu funkcję perswazyjną, pozwala nie tylko na ukazanie, kim są oni i uzasadnienie konieczności uczczenia ich pamięci, ale również dokonuje wartościowania tej grupy: mieli rację i potrafili prowadzić politykę w oparciu o tę rację. Warto jednak zurócić uwagę na to, kim są oni? Przecież nie uszyscy z tych, którzy zginęli, prowadzili politykę. Jednakże,

\footnotetext{
${ }^{6}$ Zob. A. Audiejew, Systemowe środki perswazji [w:] Manipulacja w języku..., op. cit., s. 78.

7 Zob. J. Mayen, O stylistyce utworów mówionych, Zakład Narodowy im. Ossolińskich

Wydawnictuo PAN, Wrocław - Warszawa 1972, s. 130.

8 Zob. K. Kłosińska, op. cit., s. 116.
} 
analizując wypowiedzi nadawcy, należy zauważyć, że grupa ta jest przedstawiona zawsze jako jedność - tych, którzy zginęli, tych Polaków, którzy polegli.

Dua kolejne fragmenty zawierają peryfrazę wiersza Herberta Przesłanie Pana Cogito. Oni jawią się tu jako ofiara zdrady (zostali zdradzeni o świcie), o której wspólnota my wie na pewno, niezależnie od tego, jakie będa ostateczne ustalenia. To stwierdzenie jest o tyle ciekawe, że po raz kolejny pokazuje stosunek uspólnoty do innych badań dotyczących katastrofy i innych ustaleń badaczy. Wprowadzenie w tych fragmentach kategorii oni 'ofiary' ma zurócić uwagę nie na ich wielkość i cierpienie, ale ma podkreślić fakt haniebnej zdrady dokonanej przez niesprecyzowanych bliżej niegodziwców, określonych formą bezosobową, o której będzie mowa w dalszej części wystąpienia.

Drugą grupę oni stanowi ta część narodu, która utożsamia się z poglądami reprezentowanymi przez zebranych na uroczystości:

(18) Dziesiatki tysięcy ludzi podjęty aktywność, by upamiętnić poległych, własne śledztwo prowadzi zespół parlamentarny posła Antoniego Macierewicza (2012).

(19) Kluby reprezentujace „Gazetę Polska” zorganizowaty tę i poprzednie manifestacje (2012).

Oni ma w tych przykładach wymiar ogólny, ma jednak podkreślić pouszechność i wielkie zaangażowanie niezliczonej rzeszy społeczeństua u działania na rzecz upamiętnienia polegtych.

Trzecią grupę stanowią wreszcie ci, którzy nie należą do uspólnoty określonej przez nadawcę. Są to wrogowie polityczni, ci, którzy dopuścili się zdrady:

(20) Ci, którzy chcieli zabić pamięć, przegrali. [...] ci, którzy rządza, nie mają prawa wypowiadać się w imieniu narodu polskiego (2011).

(21) Oni czynili wszystko, tamiac wszelkie reguty, żeby ta pamięć umarta, ale to się nie udawało [...]. Krótko mówiąc, to przedsięwzięcie, choć prowadzone z ogromna zaciekłościa poniosto fiasko (2016).

(22) Rzucaja w nas kamieniami, ale dojdziemy do szczytu, jeżeli będziemy maszerować w zwartym szyku (2016).

Zastosowanie w pieruszym przykładzie metonimii (ci, którzy chcieli zabić pamięć; ci, którzy rządza) pozwala nadawcy oceniać urogów politycznych skrajnie negatywnie, bez uymieniania konkretnych postaci. Stwarza to także urażenie, jakby uszyscy, którzy nie myślą tak jak uspólnota my, są źli i nie należą do narodu polskiego (nie mają prawa wypowiadać się $w$ imieniu narodu polskiego). Kolejne fragmenty dowodzą, że oni są zuykłymi chuliganami, że zachouują się na uskroś nieetycznie (tamali wszelkie reguty; rzucają kamieniami). Kategoria oni 'wrogowie polityczni' pełni jeszcze jedną ważną rolę dla wspólnoty my - pozuala bardziej zjednoczyć się we wspólnym marszu do szczytu. 


\section{Formy bezosobowe}

W mowach Jarosława Kaczyńskiego wygłaszanych w czasie rocznic katastrofy smoleńskiej pojawiają się ureszcie liczne formy bezosobowe, które służą ukazaniu przeciuników politycznych. Mirosław Karwat w artykule poświęconym perswazji w języku polityki podkreśla, że

niedookreśloność politycznych komunikatów jest suego rodzaju zabezpieczeniem przed oskarżeniami ze strony adwersarzy, a możliwość różnorakich interpretacji - zaworem bezpieczeństua, który u trudnej sytuacji pozwala wybrnąć z opresji. Niewyraźność przekazu służy także powiększeniu zakresu oddziaływania - jest potencjalnie mniej osób, które komunikatem mogłyby poczuć się urażone9 .

Zacieranie uyrazistości, ograniczanie ostrości znaków językouych w przekazach propagandowych pomaga także nadawcy w wywołaniu odpowiednich postaw, zasugerowanie mu wizji rzeczywistości pożądanej przez mówcęę.

W przemówieniach Jarosława Kaczyńskiego formy bezosobowe pojawiają się bardzo często, jednak nie można mówić, że nadawca używa ich u celu zabezpieczenia się przed ewentualnymi oskarżeniami, ponieważ w pewnym momencie ujawnia, kogo ma na myśli. Zastosowanie formy bezosobowej służy nadawcy przede uszystkim do całkowitego odcięcia się od grupy, którą ma na myśli. Jest to specyficzny sposób ignorowania tej grupy, czyli wroga politycznego:

(23) Przeszło cztery lata temu padty stowa o tym, że polskie państwo zdało egzamin. Trudno powiedzieć większa nieprawdę. Polskie państwo wtedy nie zdało egzaminu o to na poziomie elementarnym. Nie uczyniono niczego, co jest międzynarodowym standardem w takiej sytuacji. Nie zabezpieczono miejsca katastrofy, nie zabezpieczono polskiej wtasności, przyjęto skrajnie niekorzystne rozwiązania prawne, które uniemożliwity nam odwołanie się od decyzji innych, bo w efekcie decyzje przekazano Rosjanom. Nie zadbano o godne potraktowanie ciat ofiar, które byty niejednokrotnie traktowane $w$ sposób haniebny. Bez protestów znoszono niszczenie dowodów, wszyscy mogliśmy to obserwować. Odrzucono wszelkiego rodzaju propozycje zmierzające do umiędzynarodowienia śledztwa. Nie przeprowadzono sekcji zwłok. [...] Na końcu uznano upokarzające Polaków wyniki śledztwa Anodiny. Nieustannie okłamywano Polaków, nieustannie nas, Polaków okłamywano (2015)

(24) [...] uruchomiono przemyst pogardy. Zaatakowano krzyż, zaatakowano modlacych się, doszło do niestychanych aktów profanacji, do fizycznych ataków na tych, którzy tu byli. Podeptano wszystkie elementarne zasady naszej europejskiej kultury. Doszło do prawdziwej eksplozji nienawiści do polskiej tradycji - katolickiej, ale i niepodlegtościowej, którą odnawiat w swoim życiu prezydent Lech Kaczyński. To wszystko dziato

\footnotetext{
${ }_{9}$ M. Karwat, Perswazja $w$ tekstach politycznych - spojrzenie politologa, w: Język perswazji publicznej, red. K. Mosiołek-Kłosińska, M. Zgółka, Wydawnictuo Poznańskie, Poznań 2003, s. 115.

${ }^{10}$ Por. M. Bugajski, Znak językowy w tekstach oficjalnej propagandy [w:] Język a kultura, t. 1, op. cit., s. 140.
} 
się za zgoda albo wręcz na polecenie wtadz. Przecież te akty agresji działy się tuż obok funkcjonariuszy stużb mundurowych, przecież ktoś musiał nakazać gaszenie zniczy i mówienie, że to śmieci, ktoś musiał nakazać zbieranie tulipanów, które były hotdem dla śp. prezydentowej (2015).

(25) Nasza pamięć chciano zabić, bo bano się jej. Za tę tragedię, niezależnie od tego, jakie byty jej przyczyny, ktoś odpowiada przynajmniej moralnie. I odpowiadat za to poprzedni rząd (2016).

Formy bezosobowe w przemówieniach Kaczyńskiego mają przede wszystkim zdyskredytować w oczach odbiorców ówczesny rząd polski. To właśnie on w kolejnych fragmentach występuje jako najczęściej bliżej nieokreślona zła siła, zaniedbująca swoje podstawowe obowiązki wobec narodu i ojczyzny (nie uczyniono niczego, co jest międzynarodowym standardem w takiej sytuacji; nie zabezpieczono miejsca katastrofy, nie zabezpieczono polskiej własności, nie zadbano o godne potraktowanie ciał ofiar, znoszono niszczenie dowodów, odrzucono wszelkiego rodzaju propozycje zmierzające do umiędzynarodowienia śledztwa. Nie przeprowadzono sekcji zwłok; uruchomiono przemysł pogardy; zaatakowano krzyż; zaatakowano modlących się, doszło do niesłychanych aktów profanacji, do fizycznych ataków na tych, którzy tu byli. Podeptano uszystkie elementarne zasady naszej europejskiej kultury).

Nagromadzenie $u$ formie wyliczeń leksyki określającej zaniedbania i zaniechania polskiego rządu pełni funkcję oceniającą. Rząd jest tu zatem wartościowany skrajnie negatywnie, a słowa zawarte w ostatnim fragmencie: Za tę tragedię, niezależnie od tego, jakie były jej przyczyny, ktoś odpowiada przynajmniej moralnie. I odpowiadał za to poprzedni rzad pokazuje władze w jak najgorszym świetle. Zastosowanie paralelnego segmentu: Nieustannie okłamywano Polaków, nieustannie nas, Polaków okłamywano można interpretować, że rząd polski to nie Polacy.

\section{Wnioski}

Wystąpienia prezesa PiS Jarosława Kaczyńskiego podczas rocznic (a także miesięcznic) katastrofy smoleńskiej bardzo wyraźnie pokazują rozumienie uspólnoty narodowej przez móucę. Kaczyński od pieruszego analizowanego tu wystąpienia stosuje konsekwentnie formę 1 os. l. mn. my dla określenia zebranych na uroczystości przedstawicieli jego opcji politycznej oraz tej części narodu, która myśli tak samo jak on. Należy dodać, że niekiedy w jego wypowiedziach pojawia się relacja nadawczo-odbiorcza ja - wy (choć ja najczęściej jest utajone), np.: Zapytacie - a co z prawdą? Prawda musi się znaleźć w polskich dokumentach; lub ja - my (w której nadawca jawi się jako ktoś wyjątkowy dla uspólnoty, jako jej przywódca, mentor), np.: to jest nasza droga do petnego zwycięstwa i przyjdzie to petne zwycięstwo - jestem o tym gtęboko przekonany. Tego typu relacje nie były jednak przedmiotem artykułu.

Forma 3 os. l. mn. oni ma w wystąpieniach Kaczyńskiego trzy zastosowania: określa tych, którzy zginęli w katastrofie. Należy podkreślić, że kategoria oni obejmuje uszystkie 
ofiary. Kategorię tę stosuje móuca także przy określaniu ludzi, którzy zaangażowali się we uspólne działania ze zuolennikami teorii prezentowanych przez Jarosława Kaczyńskiego - prowadzą śledztwo, zbierają pieniądze na pomniki itp. Trzecią grupę określaną mianem oni prezentują przeciunicy polityczni, ukazywani jako ci, którzy starają się utrudnić dociekanie prawdy, którzy służą kłamsturu, dopuszczają się prowokacji, by nie pozwolić na odkrycie prawdy. Największym wrogiem uspólnoty my i polskiego narodu jest polski rząd, który nie uczynił niczego, by zbadać przyczyny katastrofy.

Analizując język przemówień Jarosława Kaczyńskiego, nie można pominąć jeszcze trzeciej kategorii - form bezosobowych, stosowanych także dla ukazania wroga politycznego i jego szczególnie niegodziwych działań. Pokazanie zła, którego dopuszczają się uróg polityczny (polski rząd z premierem Donaldem Tuskiem na czele) i jego zwolennicy usprawiedliwia podział narodu wprowadzony przez Jarosława Kaczyńskiego. $\mathrm{Z}$ tego punktu widzenia u pełni uzasadnione jest zatem stwierdzenie, że ci ludzie nie maja prawa wypowiadać się w imieniu narodu polskiego.

\section{Bibliografia}

Audiejew A., Systemowe środki perswazji [w:] Manipulacja w języku, red. P. Krzyżanouski, P. Nowak, Wydawnictwo Uniwersytetu Marii Curie-Skłodouskiej, Lublin 2004, s. 71 - 80. Barańczak S., Słowo - perswazja - kultura masowa, „Twórczość” 1975, nr 7.

Bugajski M., Znak językowy w tekstach oficjalnej propagandy [w:] Język a kultura. Podstawowe pojęcia i problemy, red. J. Anusieuicz, J. Bartmiński, Wiedza o Kulturze, Wrocław 1991, s. $137-141$.

Fras J., Komunikacja polityczna: wybrane zagadnienia gatunków i języka wypowiedzi, Wydawnictuo Uniwersytetu Wrocłauskiego, Wrocław 2005.

Kamińska-Szmaj I., Propaganda, perswazja, manipulacja - próba uporządkowania pojęć [w:] Manipulacja w języku, red. P. Krzyżanouski, P. Nowak, Wydaunictwo Uniwersytetu Marii Curie-Skłodouskiej, Lublin 2004, s. 13-28.

Karwat M., Perswazja w tekstach politycznych - spojrzenie politologa [w:] Język perswazji publicznej, red. K. Mosiołek-Kłosińska, T. Zgółka, Wydawnictuo Poznańskie, Poznań 2003.

Kłosińska K., Rola procesów nominacyjnych w tworzeniu opozycji „my”|"oni” w języku polityki po 1989 roku [w:] Manipulacja w języku, red. P. Krzyżanouski, P. Nowak, Wydaunictuo Uniwersytetu Marii Curie-Skłodowskiej, Lublin 2004, s. 115-122.

Mayen J., O stylistyce utworów mówionych, Zakład Narodouy im. Ossolińskich - Wydaunictuo PAN, Wrocław - Warszawa 1972.

Walczak B., Co to jest język polityki [w:] Język a kultura. Język polityki a wspótczesna kultura polityczna, red. J. Anusiewicz, B. Siciński, Wiedza o Kulturze, Wrocław 1994.

Zaleska Z., Perswazja w języku polityki, „Dialogi Polityczne” 2008, nr 9, s. 255-266.

\section{Netografia}

2011 r. http://www.archiwum.wyborcza.pl/Archiwum/0,0.html.

2012 r.: http://www.rp.pl/artykul/857907. 
My naród - czyli kło?...

2013 r.: http://natemat.pl/57487.

2014 r.: http://karta.telewizjarepublika.pl/kaczynski-dokonczmy-solidarnosciowa-rewolucje, 5757. html.

2015 r.: http://wpolityce.pl/smolensk/240460.

2016 r.: https://www.wprost.pl/historia/535700.

2017 r.: http://www.fakt.pl/wydarzenia/polityka/7-rocznica-katastrofy-smolenskiej-przemowienie-jaroslawa-kaczynskiego/rcvbkle. 